\title{
Dampak Bisnis Burung Walet Terhadap Perubahan Perekonomian Masyarakat Betung Banyuasin
}

\author{
Totok Sudiyanto \\ Akuntansi, Fakultas Ekonomi Universitas PGRI Palembang, \\ email: totoktajir78@univpgri-palembang.ic.id
}

\begin{abstract}
ABSTRAK
Perumusan masalah dalam penelitian ini adalah apakah ada dampak bisnis burung walet terhadap perubahan perekonomian masyarakat Betung Banyuasin. Penelitian ini dilakukan pada masyarakat Betung Banyuasin yang mempunyai bisnis burung walet. Sampel dalam penelitian ini adalah masyarakat Betung Banyuasin yang mempunyai bisnis walet sebanyak 150 orang. Sedangkan sampel yang diambil sebanyak 30 orang. Hasil penelitian yang diperoleh menunjukkan bahwa ada dampak bisnis burung walet terhadap perubahan perekonomian masyarakat Betung Banyuasin. Hal ini dapat dilihat dari hasil pertanyaan-pertanyaan yang diajukan, wawancara dan observasi yang telah dilakukan peneliti.
\end{abstract}

Kata Kunci: Dampak Bisnis Burung Wallet, Perubahan Perekonomian Masyarakat.

\section{A. Latar Belakang}

Betung merupakan daerah bagian dari kabupaten Banyuasin. Daerah ini adalah daerah dataran rendah atau perairan oleh karena itu mata pencaharian di daerah ini mayoritas penduduknya adalah bertani dan bercocok tanam sayur-sayuran. Pada tahun 1998 mulai timbul tanda-tanda adanya perubahan yaitu dalam bidang perekonomian. Perubahan tersebut adalah adanya Burung Walet yang pertama kali menghuni gedung-gedung kosong yang ada disekitar pasar lama. Pada saat itu pasar ini sudah tidak di pakai sebab sekarang pasar tersebut sudah pindah lokasi sehinga banyak bangunan kosong. Dulu orang-orang tidak mengetahui bahwa itu burung walet yang sangat berguna, namun lama kelamaan mereka mulai mengetahuinya. Sejak itulah akhirnya timbul ide masyarakat untuk membudidayakan burung walet tersebut karena air liur burung walet mempunyai nilai jual yang sangat tinggi yaitu berkisar antara Rp 15.000.000 tiap $1 \mathrm{~kg}$.
Perkembangan budidaya walet semakin pesat karena masyarakat mulai berlomba-lomba untuk membangun gedung-gedung walet yang didisain sebaik mungkin agar burung-burung walet tertarik masuk ke dalamya. Masyarakat juga mulai mempelajari habitat burung walet. Disamping renovasi gedung diperlukan juga kaset walet untuk memancing burung walet masuk kedalam gedung.

Pembudidayaan burung walet bukan hal yang mudah, banyak gedung-gedung yang sudah dibangun namun kosong karena tidak semua gedung yang dibuat dapat menarik burung walet masuk kedalamnya. Diperlukan waktu yang lama agar gedung dapat dihuni sekitar 1 sampai 2 tahun. Hal tersebut merupakan kendala utama bagi masyarakat, disamping modal yang besar dan kekhawatiran mereka kalau saja gedung yang mereka buat ternyata tidak dihuni dan kosong begitu saja. Hal ini dapat menimbulkan kerugian besar, lain halnya kalau burung walet tersebut datang dengan sendirinya. Dari tahun 1998 sampai 2008 ini perubahan 
masyarakat Betung semakin maju, salah satu penyebab utamanya adalah burung walet karena dengan burung walet itulah mereka dapat memetik hasil yang sangat besar yang dapat mengganti mata pencarian pokok mereka.

Dapat dibandingkan tahun sebelum ada bisnis burung walet dengan sesudah ada bisnis burung walet, perbandingannya sangat jauh sekali. Sebelum ada bisnis burug walet perekonomian masyarakat Betung sangat meprihatinkan karena mereka yang bergantung pada usaha dagang, sawah, dan kebun. Pedagang bisa mengeruk keutungan bila petani dan perkebunan bisa menghasilkan panen yang bagus, sedangkan petani bercocok tanam hanya 1 tahun sekali, karena mereka mengandalkan air pasang surut. Itu semua menyebabkan perekonomian masarakat Batung Banyuasin sulit berubah, karena mereka tidak mempunyai mata pencarian lain, selain dagang, bertani, dan berkebun.

Seiring dengan pesatnya bisnis walet membuat Betung Banyuasin semakin maju. Semua itu dapat terlihat dari bangunan rumah mereka, bangunan rumah yang semula hanya rumah kayu kini berubah menjadi rumah batu, dan yang semula rumah batu lebih di percantik dengan tamantaman kecil dan pagar-pagar yang kokoh. Begitu juga dengan jalan yang semula tanah dan terkena hujan becek sekarang ditimbun dengan batu-batu dan pasir. Masyarakat Betung Banyuasin yang semula mengkonsumsi air hujan kini mengkonsumsi air meneral dalam bentuk kemasan. Selain itu kendaraan semakin ramai, yang semula hanya sepeda kini berganti dengan beraneka jenis motor. Pendidikan di Betung juga semakin maju, masyarakat tidak segan-segan menyekolah kan anak mereka sampai kejenjang yang lebih tinggi. Tidak ketingalan juga dengan bangunan Masjid, Gereja dan Pura yang kokoh dan megah membuat Betung Banyuasin semakin indah.

\section{B. Rumusan Masalah}

Berdasarkan latar belakang maka dirumuskan permasalahan sebagai berikut "Apakah ada dampak bisnis burung walet terhadap perubahan perekonomian masyarakat di daerah Betung Banyuasin".

\section{Metode Penelitian}

Metode yang digunakan dalam penelitian ini adalah kualitatif yaitu mengumpulkan data, menganalisis data dan menarik kesimpulan serta tidak dilakukan perhitungan.

\section{Populasi dan Sampel}

\section{1) Populasi}

Populasi adalah : keseluruan objek penelitian (Arikunto, 2010:108). Dalam hal ini yang menjadi populasi adalah seluruh masyarakat Betung Banyuasin yang memiliki bisnis burung walet adalah sebanyak 150 orang.

\section{2) Sampel}

Sampel adalah : Sebagian atau wakil populasi yang diteliti (Arikunto, 2010:109). Menurutnya bila subjek kurang dari 100 orang lebih baik diambil semua sehingga penelitianya merupakan penelitian populasi, jika jumlah objek lebih dari 100 orang dapat diambil $10-15 \%$ atau $20-25 \%$ atau lebih tergantung setidaknya dari kemampuan peneliti. Sejalan dengan penelitian di atas, maka penulis menentukan jumlah sampel sebesar 20\%. Sampel penelitian ini adalah $20 \% \times 150=30$. Jadi sampel yang diambil dalam penelitian ini sebanyak 30 orang. 


\section{E. Teknik Pengumpulan Data}

1) Data Primer

Data Primer adalah sumber data yang langsung memberikan data kepada pengumpul data (Sugiyono, 2018:129) data primer yang penulis kumpulkan dapat diperoleh dengan cara sebagai berikut :

a. Tehnik Ovservasi

Yaitu mengumpulkan data dengan mencatat pola prilaku orang, objek atau kejadian-kejadian melalui cara statistik.

b. Tehnik wawancara

Yaitu peroses memperoleh keterangan untuk tujuan penelitian dengan cara Tanya jawab langsung antara pewawancara dan diwawancarai. Dalam penelitian ini pelukis mewawancarai masyarakat Betung Banyuasin yang sudah berhasil mempelihara burung walet (orang-orang yang dijadikan sampel).

2) Data Sekunder

Data sekunder adalah merupakan sumber yang tidak langsung memberikan data kepada pengumpulan data, misalnya lewat orang lain atau lewat dokumen (Sugiyono, 2018:129).

\section{F. Hasil Penelitian dan Pembahasan}

Pada bab ini penulis akan menganalisis masalah dampak bisnis burung walet terhadap perubahan masyarakat Betung Banyuasin. Perekonomian yang begitu pesat mengenai dampak burung walet dapat dirasakan oleh masyarakat Betung Banyuasin, karena dampaknya begitu besar terhadap perubahan perekonomian masyarakat Betung Banyuasin.

Betung Banyuasin dulunya daerah kecil dan daerah transmigrasi, sekarang sudah berubah menjadi kota kecil yang di peneuhi oleh rumahrumah bertingkat dan gedung-gedung walet yang sudah begitu banyak bagai jamur di musim hujan. Semua ini dapat dilihat dari pertanyaan-pertanyaan, wawancara, dan observasi yang peneliti lakukan yang memberi informasi bahwa walet merupakan harta karun yang bernilai jutaan rupiah bahkan miliyaran yang dampaknya sangat luar biasa bagi yang mempumyai pembudidayaan burung walet. Dalam penelitian ini masyarakat yang akan di teliti sebanyak 30 orang yang memiliki bisnis walet.

Dibawah ini adalah tabel namanama masyarakat yang akan diteliti dan mengisi pertanyaan yang sudah disediakan.

Tabel 1

NAMA-NAMA MASYARAKAT

BETUNG BANYUASIN YANG MEMILIKI BISNIS WALET

\begin{tabular}{|c|c|c|c|}
\hline No & Nama & Umur & Pekerjaan \\
\hline 1 & Jumheri & 45 & Tani \\
\hline 2 & Ahmat & 45 & Dagang \\
\hline 3 & Kuyung Agus & 49 & Dagang \\
\hline 4 & Said & 58 & Dagang \\
\hline 5 & Indra & 37 & Tani \\
\hline 6 & Qumroni & 50 & Dagang \\
\hline
\end{tabular}




\begin{tabular}{|c|c|c|c|}
\hline 7 & Fikri & 55 & Dagang \\
\hline 8 & Suwardi & 53 & Dagang \\
\hline 9 & Rudiansyah & 49 & Tani \\
\hline 10 & M. Yusuf & 54 & Tani \\
\hline 11 & Heri & 51 & Tani \\
\hline 12 & Madon & 42 & Tani \\
\hline 13 & Mulyadi & 48 & Dagang \\
\hline 14 & Johan & 41 & Tani \\
\hline 15 & Saman & 42 & Tani \\
\hline 16 & Rusman & 50 & Tani \\
\hline 17 & Oki & 54 & Tani \\
\hline 18 & Sadirin & 55 & Tani \\
\hline 19 & Supri & 49 & Tani \\
\hline 20 & Harun & 56 & Tani \\
\hline 21 & Sukardi & 35 & Tani \\
\hline 22 & Izharudin & 54 & PNS \\
\hline 23 & Sugito & 54 & Tani \\
\hline 24 & Sukarni & 55 & Dagang \\
\hline 25 & Joko Subroto & 52 & Tani \\
\hline 26 & Ruslan & 40 & Dagang \\
\hline 27 & Saipul & 56 & Dagang \\
\hline 28 & Wasmin & 44 & Tani \\
\hline 29 & Warno & 55 & Tani \\
\hline 30 & Yusri & 49 & Tani \\
\hline
\end{tabular}

Dari tabel diatas dapat kita lihat bermacam-macam jenis pekerjaan mereka dan mayoritas penduduknya adalah bertani. Bila mereka hanya mengandalkan pekerjaan mereka maka hasilnya sangat kurang dan hanya cukup untuk mencukupi kebutuhan sehari-hari tanpa bisa menyisihkan untuk ditabung atau mencukupi kebutuhan yang lain. Merekapun mulai membuka usaha lain yaitu bisnis walet, mereka melihat bisnis walet sangat cerah.

\section{Analisis Data Jawaban Responden}

Pertanyaan-pertanyaan yang telah di sebarkan kepada 30 orang pemilik bisnis walet dan masing-masing pertanyaan memiliki dua jawaban yaitu Ya dan Tidak. Pertanyaan tersebut terdiri dari 15 pertanyaan yang berhubungan dengan dampak bisnis walet adapun pertanyaannya dan jawaban dari responden adalah sebagai berikut

1. Apakah pendapatan anda sebelum ada bisnis walet lebih dari Rp. 1.000 .000 perbulan ?

Dari pertanyaan di atas 10 orang menjawab Ya dan 20 Tidak. Dari 
jawaban tersebut dapat kita simpulkan bahwa, betapa kecilnya pendapatan mereka sebelum mempunyai bisnis burung walet..

2. Apakah pendapatan anda sesudah ada bisnis walet lebih dari Rp. 1.000 .000 perbulan?

Dari pertanyaan di atas 30 orang menjawab Ya dan tidak ada yang menjawab tidak, dapat kita simpulkan bahwa, dengan bisnis walet perekonomian mereka meningkat dari yang kurang baik menjadi baik.

3. Apakah dengan bisnis walet kehidupan anda lebih baik ?

Dari pertanyaan di atas 30 orang menjawab Ya dan tidak ada yang menjawab tidak, alasan mereka adalah karena bisnis walet sangat menguntungkan. Menurut mereka sebelum mereka mempunyai bisnis burung walet kehidupan mereka kurang baik, tetapi semenjak mereka membudidayakan burung walet kehidupan mereka menjadi lebih baik dibandingkan dengan sebelum membudidayakan burung walet.

4. Apakah bisnis walet memberikan keuntungan bagi anda?

Dari pertanyaan di atas 30 orang menjawab $\mathrm{Ya}$, dan tidak ada yang menjawab Tidak. Menurut mereka dengan bisnis walet mereka merasa diuntungkan dan mereka dapat menguntugkan hidup mereka dengan bisnis ini. Bila dibanding kan dengan modal yang mereka keluarkan itu tak sebanding dengan hasil yang mereka dapatkan, karena untung mereka berlipat-lipat jauh dari modal yang mereka keluarkan.

5. Apakah anda tidak terusik dengan suara-suaranya?

Dari pertanyaan di atas 30 orang menjawab Tidak, karena mereka sudah terbiasa dengan suarasuara yang ditimbulkan oleh walet tersebut.

6. Apakah dengan bisnis walet dapat mengupah perekonomian anda?

Dari pertanyaan di atas 30 orang menjawab Ya dan tidak ada yang menjawab Tidak, menurut mereka semenjak ada bisnis walet perekonomian mereka berubah drastis dibanding sebelum ada bisnis walet. Perekonomian yang semula kurang baik, kini menjadi sangat baik. Itu semua dikarenakan Bisnis walet yang mereka geluti.

7. Apakah bisnis walet memberi prospek untuk masa depan anda ?

Untuk pertanyaan ketuju jawaban ini juga masih sama dengan jawaban-jawaban sebelumnya. Ke 30 orang menjawab Ya, dan tidak ada yang menjawab tidak. Menurut mereka bisnis walet bisnis yang sangat menjanjikan dan prospeknya sangat cerah, itu semua dapat dibuktikan karena mereka sudah merasakan hasil dari bisnis burung walet ini..

8. Apakah penduduk disekitar anda tertarik untuk berbisnis walet ini ? Dari pertanyaan di atas 25 orang menjawab $\mathrm{Ya}$ dan 5 orang menjawab tidak. 25 orang yang menjawab Ya memberi alasan menurut mereka masyarakat disekitar ingin seperit mereka menjadi pembisnis burung walet, tetapi sebalik nya 5 orang yang menjawab tidak. Mereka memberi alasan masyarakat disekitar mereka tidak berminat karena mereka takut bisnisnya tidak berhasil dan mereka tidak siap mengalami kerugian.

9. Apakah anda menekuni bisnis walet ini ? 
Dari pertanyaan di atas 30 orang menjawab Ya, dan tidak ada yang menjawab Tidak. Setelah saya teliti dan tanya jawab dengan mereka, mereka sangat menekuni bisnis walet ini bahkan mereka juga mempelajari karakteristik burung walet dan tidak ragu mereka berburu bukubuku untuk lebih mengenal sifatsifatnya dan habitat dari burung walet ini.

10. Apakah dengan bisnis walet ini anda merasa dirugikan ?

Dari pertanyaan di atas 30 orang menjawab Tidak, dan tidak ada yang menjawab Ya. Alasan mereka untuk saat ini mereka tidak pernah merasa dirugikan dan sebaliknya mereka merasa diuntugkan dengan bisnis ini, bahkan mereka mempunyai rencana untuk meperluas bisnis ini.

11. Apakah anda mempunyai rencana memperluas bisnis walet ini ?

Dari pertanyaan di atas 30 orang menjawab $\mathrm{Ya}$, dan tidak ada yang menjawab Tidak. Seperi telah dijelaskan pada jawaban ke 10 mereka akan memperluas bisnis ini karena mereka merasa diuntugkan dan tidak merasa dirugikan.

12. Apakah anda mempelajari tehniktehnik khusus untuk memelihara burung walet

Dari pertanyaan di atas 30 orang menjawab $\mathrm{Ya}$, dan tidak ada yang menjawab Tidak. Alasan mereka, mereka ingin lebih mengenal kehidupan burung walet dan tehnik-tehnik pembudidayaan burung walet karena burung walet ini berbeda dengan burung yang sering dipelihara dan perlu tehniktehnik khusus untuk memelihara burung ini agar bisnis mereka bisa cepat berkembang.
13. Apakah anda berbagi kiat-kiat khusus terhadap para pemula bisnis walet?

Dari pertanyaan di atas 30 orang menjawab Ya, dan tidak ada yang menjawb tidak. Karena menurut mereka bila saling berbagi kiatkiat khusus cara berbisnis walet suatu saat bila kita mengalami masalah dengan bisnisnya pembisnis yang lain memberi masukan cara mengatasinya.

14. Apakah masyarakat disekitar anda terusik dengan bisnis ini ?

Dari pertanyaan di atas 30 orang menjawab Tidak, dan tidak ada yang menjawab Ya. Karena masyarakat sekitar sudah terbiasa dan akrab dengan suara-suara yang ditimbulkan oleh burung walet tersebut.

15. Apakah anda sudah mempersiapkan diri bila suatu saat nanti terjadi dampak yang buruk dengan bisnis walet?

27 orang menjawab $\mathrm{Ya}$ dan 3 orang menjawab Tidak. Ke 27 orang terrsebut sudah mempersiapkan diri bila terjadi dampak yang buruk bagi mereka dengan cara menabung atau membangun rumah yang jauh dari gedung-gedung walet, dan yang 3 orang menjawab tidak karena mereka merasa tidak perlu mempersiapkan apa pun. Menurut mereka tidak perlu ada yang dipersiapkan dan tidak ada yang perlu yang ditakutkan.

Selain dari pertanyaan peneliti juga mewawancari secara langsug kepada para pembisnis tentang bangunan rumah walet, bagai mana mereka memancing burung walet agar mau masuk dan tinggal di gedung tersebut, dan bagai mana bila ada musuh walet seperti burung hantu. Dari pertanyaan-pertanyaan yang penulis 
ajukan secara langsung, penulis mempunyai jawaban sebagai berikut :

$>$ Bangunan rumah walet, menurut mereka bangunan rumah walet harus dibangun tinggi, bisa dibangun rendah tetapin teperaturnya harus diatur seperti ruangan yang dibuat lebih luas, ketebalan atap, ktebalan dinding juga jumlah pentilasi perlu diperhatikan, karena burung walet ini senag akan suasana yang dingin. Dinding-dinding gedung walet lebih baik dicat, karena cat bisa meredam terik matahari agar tidak terlalu panas dan bisa menjaga kesejukan gedung walet.

Para pembisnis memancing burung walet dengan suara-suara yang mirip dengan suara burung walet pada umumnya, agar burung walet yang berterbangan terpikat untuk memasuki gedung. Cara ini terbilang sangat ampuh, tingkat keberhasilan pun lebih cepat dan memuaskan. Biasanya alat yang digunakan untuk pengoperasian suara-suara walet tiruan mengunaka CD (Compact Disc) atau kaset. Selain itu biasanya para pembisnis menaruh kotoran walet, aromaaroma tersebit bertujuan untuk menebar kan bau khas di gedung baru agar berkesan bahwa gedung telah dihuni.

Cara mengatasi musuh-musauh walet, seperti burung hantu adalah denga memasang lampu di dekat pintu masuk dan lampu hanya dinyalakan bila malam hari.

Berdasarkan dari jawabanjawaban yang telah di berikan oleh responden, penulis menyimpulkan bahwa ada dampak bisnis burung walet terhadap perekonomian masyarakat Betung Banyuasin. Mereka ada yang berhasil mengembangkan usaha dan memperbesar nilai bisnisnya yang makin lama makin maju tetapi ada pula yang gagal. Bagi mereka yang berhasil, kegiatan bisnis makin menarik dalam kehidupan mereka.

Semua manusia mempumyai kebutuhan yang beraneka, dan kebutuhan itu harus dipenuhi, yaitu berupa kebutuhan makan, pakaian, dan perumahan, dalam istilah populernya, kebutuhan akan sandang, pangan, dan papan, dari bentuk sederhana sampai bentuk mewah, canggih dan sangat mahal dengan segala perlengkapan. Menurut Alam dalam buku pengantar bisnis salah satu keuntungan dari pertumbuhan ekonomi adalah meningkatkan setandar hidup. Dari buku pengantar ekonomi dapat dilihat bila perekonomian meningkat maka standar hidup masyarakat juga meningkat. Dibawah ini sebab-sebab kegagalan dan kesuksesan dalam berbisnis menurut Alma (2009) dalam buku pengantar bisnis

Sebab-sebab kegagalan dalam berbisnis

> Tidak mampu mengelola bisnis, mungkin tidak mampu mengambil keputusan segera, tidak mengetahui hakekat bisnis yang di gelutinya dan sebagainya.

$>$ Lalai, artinya terlalusantai menjalankan bisnis.

$>$ Tidak mampu melaksanakan pengawasan, baik terhadap perliaku kariyawan/pembantunya, maupun terhadap barang-barang dan uang.

Modal sangat kecil dan tidak mampu meminjam modal.

Hal-hal yang membuat kesuksesan

$>$ Ada usaha, kerja keras dan dedikasi tinggi dari pemilik, semangat untuk memajukannya tinggi, optimis banyak bergaul. 
Prospek yang dibutuhkannya, atupun yang dijalaninya memang dibutuhkan, sesuai dengan selera dan disegani oleh masyarakat sekitar.

Menurut Rahman dalam buku pembudidayaan burung walet dituliskan cara-cara atau kiat-kiat berbisnis walet agar bisnis itu menguntugkan ada 8 yaitu sebagai berikut :

1. Mengenal karktaristik walet

Sebelum kita membuka bisnis burung walet sebaiknya kita mengenak karateristik birung walet, apa makanan burung walet dan bagai mana gaya hidup burung walet.

2. Jenis-jenis sarang walet dan manfaatnya

Walet mempunyai beberapa jenis yaitu, sarang walet gua dan sarang walet rumahan. Manfaat dari sarang walet antara lain adalah bias dijadikan obat antara lain untuk melawan penurunan kekepalan tubuh pada penderita AIDS dan juga untuk bahan kosmertik..

3. Mendesain bangunan untuk budidaya walet

Sebelum membangun gedung walet sebaiknya memperhatikan Lokasi, Iklim, dan kondisi lingkungan. Selain itu juga perlu di perhatikan teperatur, kelembaban, cahaya, keamanan dan ukuran gedung.

4. Tehnik memancing dan penerapannya membuat walet betah tinggal di gedung dan berproduksi

Ada 6 cara untuk memancing walet yaitu :

- Pancing telur atau putar telur

- Menggunakan seriti kembang

- Menggunaka suara

- Menggunakan aroma

- Menggunakan pakan dan air
- Menggunakan sarang kertas

5. Membuat walet betah tinggal di gedung dan berproduksi.

Cara membuat walet betah betah tinggal digedung :

- Menciptakan kondisi yang nyaman

- Menyediakan pakanalam

6. Kiat menetaskan telur dan merawat anak walet

Sebelum kita menetaskan telur walet sebaik nya kita mempelajari:

- Karakteristik burung walet

- Karakteristik anak walet

- Pemetasan telur

- Perawatan anak walet

7. Hama walet dan cara mengendalikannya

Hama yang sering mengusik burung walet adalah :

a. Serangga

- Kepinding

- Semut

- Kecoak

b. Tikus

c. Kekelawar

d. Burung hantu

8. Pemanenan dan penanganan sarang walet.

Berdasarkan dari 8 cara atau kiatkiat berbisnis sarang walet penulis dapat menyimpulkan bahwa masyarakat Betung Banyuasin sudah memenuhi sarat-sarat berbisnis walet, walaupn tidak semua sarat-sarat tersebut dijalankan. Tetapi terbukti Masyarakat yang semula berpenghasilan minim, karena bisnis walet penghasilan mereka meningkat. Perekonomian mereka juga berubah drastis, dapat penulis lihat dari hasil observasi dan wawancara yang penulis lakukan langsung dilapangan terhadap 30 orang pembisnis burung walet. Bisnis walet juga memberi keuntungan, kehidupan mereka menjadi lebih baik dari sebelumnya, prospek bisnis ini juga sangat cerah untuk masa depan. 
Karena itu para pembisnis menekuni bisnis ini, dan berkeinginan mengembang kan bisnis ini oleh sebab itu para pembisnis mempelajari tehniktehnik pembudidayaan burung walet. Masyarakat disekitar mereka juga tertarik dengan bisnis ini, karena bisnis ini memberi untung yang besar.

\section{G. Kesimpulan dan Saran \\ 1. Kesimpulan}

a) Dari permasalahan yang ada, dapat penulis simpulkan bahwa ada dampak bisnis burung walet terhadap perubahan perekonomian masyarakat Betung Banyuasin. Hal itu dapat penulis lihat dari wawancara, observasi, dan pertanyaan-pertanyaan yang penulis lakukan.

b) Betung Banyuasin dulunya sangat sepi tapi kini menjadi kota kecil yang ramai, baik ramai kendaraan, gedung-gedung yang tinggi, rumah yang bertingkat dan ditambah suara-suara burung walet yang bersahut-sahutan yang menjadikan Betung Banyuasin makin ramai. Selain itu dampak lain adalah dalam pendidikan, penulis melihat dari tahun-ketahun jumlah penduduk yang melanjutkan keperguruan tinggi semakin banyak. Kini mereka berlomba-lomba memberikan pendidikan yang terbaik untuk masa depan anakanak mereka.

\section{Saran}

Pada bab ini penulis menyarankan agar para pembisnis burung walet lebih memperhatikan lingkungan sekitar. Karena burung walet selain membawa dampak yang positif juga membawa dampak yang negatif bila kita tidak memperhatikannya, dampaknya yaitu dibidang kesehatan, maka dari itu penulis menyarankan agar para pembisnis burung walet lebih memperhatikan dampak yang kurang baik dari burung walet tersebut sebelum terjadi hal-hal yang tidak di inginkan.

\section{DAFTAR PUSTAKA}

Alma, Buchari. 2009. Pengantar Bisnis. Bandung: CV Alfabeta.

Arikunto, Suharsimi. 2010. Prosedur Penelitian Suatu Pendekatan Praktek. Jakarta : PT. Rinika Cipta.

Sugiyono. 2018. Metode Bisnis. Bandung, Alfabeta. 